\title{
A SYSTEMATIC REVIEW OF LITERATURE ON CLINICAL LEGAL EDUCATION: A TOOL FOR RESEARCHERS IN RESPONDING TO
}

\section{AN EXPLOSION OF CLINICAL SCHOLARSHIP}

\section{Tribe Mkwebu ${ }^{1}$}

Northumbria University, UK

\begin{abstract}
Identifying where my research, on influential factors to consider in the establishment and sustainability of clinical legal education programmes, fitted within the existing clinical scholarship was by no means an easy task hence the decision to undertake a Systematic Review of literature. The current explosion of clinical scholarship seems to have been influenced by Jerome Frank's call for reform in legal education when in 1933, he asked "Why not a Clinical-Lawyer School?" (Frank, 1933). A constant construction of clinical scholarship is critical in understanding many of the facets of clinical legal education so as to sustain clinical programmes and foster new ones. Yet a 'boom' in literature scares the life out of many a scholar and novice researchers when attempting to find articles that specifically answer research questions. This paper therefore offers guidance in conducting a Systematic Review of literature on clinical legal education using a Grounded Theory method. Through a five- stage process that involved the formulation of a research question and protocol; the use of systematic methods to identify, select and critically appraise relevant journal articles,
\end{abstract}

\footnotetext{
${ }^{1}$ Tribe Mkwebu is a third year PhD Candidate and Associate Lecturer, School of Law, University of Northumbria, United Kingdom
} 
this paper outlines each formal methodological step in identifying and selecting journal articles for inclusion in answering the following research question: What factors are influential in the establishment and sustainability of clinical legal education programmes in Zimbabwe? The numbers of selected articles were presented in a PRISMA flow diagram. A final selection of ninety-one journal articles was juxtaposed; integrated and tabulated to produce an overarching explanation which attempts to account for the range of findings (Mays et al., 2005a) of the review. Through the process of synthesis, I endeavoured to contribute significant added value to my review through an examination of the composite evidence base for similarities of the articles, whether related to the homogeneity or indeed their relatedness of findings. The type of epistemology I favour for my research has also been influenced partly by the methods and findings undertaken in this review (Carter and Little, 2007). The paper concludes by suggesting that a Systematic Review method, rather than a Narrative Review, should be a researcher's tool in responding to an explosion of clinical scholarship.

Keywords - Boolean logic; Boolean operators; database selection; record keeping; clinical legal education; systematic review of literature; narrative review; Zimbabwe

\section{INTRODUCTION}

Knowing what information already exists before answering a research question is as important as successfully completing a given research project, hence the need for a literature review of the area under research. Different types of literature reviews exist but two are commonly used in research, i.e. narrative reviews and systematic reviews. According to Kirkevold (1997), a Narrative Review summarises different primary studies from which conclusions may be drawn into a holistic interpretation contributed by the reviewer's own experience, existing theories and models. On the other hand, a Systematic Review of literature is a type of literature review that is 
designed to methodologically locate, appraise and synthesise the best available literature that can be used to answer a specific research question (Boland et al., 2014). The main purpose for undertaking a Systematic Review of literature for my research on influential factors to consider in the establishment and sustainability of clinical programmes within law, schools was to investigate the terrain and assess the positive and negative aspects of the Zimbabwean context in relation to clinical programmes.

\section{WHY A SYSTEMATIC REVIEW OF LITERATURE?}

While I accept that Narrative Reviews have an important role in research because they provide readers with an up to-date knowledge to answer specific topic or theme, they do not describe the methodological approach that would permit the minimisation of the risk of bias in selecting journal articles that answer a research question. The freedom to unsystematically pick and choose papers that support one's view is clearly a biased approach and using a review that has any kind of bias can lead to inconclusive findings. Situating the research project in the literature was by no means an easy task and more often than not, as doctoral researchers, we are more likely to fall into the trap of reading and reading without writing, especially where a lot of material has been written on the area of research. In order that I retrieved literature that would be relevant to the research question and enable my 
research to make an original contribution to knowledge on clinical legal education, it was important that I knew what sort of information on law clinics already exists. I was intimidated by the amount of literature on clinical legal education. At first, it was not easy identifying where my research fitted within the existing clinical scholarship because of the 'boom' in literature. The current explosion of clinical scholarship seems to have been influenced by Jerome Frank when in 1933, almost 82 years ago, he asked "Why not a Clinical-Lawyer School?" Current debates and recent developments in clinical legal education seem to have focused renewed attention upon Frank's influential question. Frank's plea for clinical-lawyer schools has resulted in an extensive literature on clinical legal education. It is this attention that has seen an emergence of keen researchers and clinicians around the globe constantly writing on various clinical legal education issues.

As descriptive as they seem to be in their various responses to Frank's question, clinical researchers constantly argue that every law school should have a clinical component within its legal education curriculum, staffed by clinicians with the experience in the practice of law for the purpose of producing lawyers fit for practice. Almost 82 years on, the debate by the legal profession, the law faculty, the law students and society rages on. Stakeholders are now forced to question with greater intensity whether or not the training of future lawyers prepares them adequately for the future practice of law. As such, I ended up having to deal with a large volume of literature that made keeping up with research evidence in this area 
of law an impossible feat. It is not unusual for the number of published papers in clinical legal education to run into several thousands. It is, therefore, this explosion in clinical legal education publishing that made me decide to undertake a Systematic Review of literature in order to keep up with research evidence.

\section{Systematic Review Aims}

The Systematic Review process I undertook aimed at:

1. establishing whether or not there has been any research on clinical legal education from a Zimbabwean context to avoid reinventing the wheel;

2. optimising efficiency by only concentrating on literature relevant to the phenomena being investigated;

3. locating and using specific literature in answering the research question by highlighting influential factors in the establishment and sustainability of clinical programmes; and

4. identifying knowledge gaps in literature on clinical legal education through a rigorous identification, evaluation and a summary of the findings of all relevant individual journal articles on clinical scholarship.

\section{Systematic Review Method}

In order to locate literature relevant in answering my research question, I adopted a search strategy that involved a five-stage iterative process; DEFINE; SEARCH; SELECT; ANALYSE and PRESENT, using a Grounded Theory method that aids understanding of the place of a Systematic Review in research (Webster and Watson, 
2002). The first three stages were part of a search strategy that followed a specific method in locating existing studies; in selecting and evaluating articles in such a way that "allows reasonably clear conclusions to be reached about what is and is not known." (Denyer and Tranfield, 2009: 671). The ANALYSE and PRESENT stages are discussed in a separate paper that describes a process of analysis and synthesis of the selected journal articles by reporting and discussing findings of the review using a Grounded Theory approach (Mkwebu, 2016, in preparation).

\section{Research question formulation}

I found out that most structures for formulating questions use the health services research question formulation framework, patient-intervention-comparison-outcome (PICO). I considered this framework. I decided against the use of PICO for two reasons. First, PICO is mostly used in health services research. My research on law clinics is purely social scientific in nature. Secondly, there is an alternative structure within the social sciences, i.e. the SPICE framework (Booth, 2006). I chose the SPICE framework because clinical legal education is a social science subject. The SPICE mnemonic was a suitable framework because it recognises that evaluations within social science areas of research are typically subjective and require definition of the specific stakeholder view (Booth, 2006).

The resultant SPICE framework for the formulation of this study's research question comprised of the following: 
- Setting - where? Zimbabwe, Developing Country, University of Zimbabwe and Midlands State University

- Perspective - for whom? The Global Clinical Movement, The Students, The General Public, Politicians, The Legal Profession, University of Zimbabwe and Midlands State University, Faculty of Law Lecturers and Law Clinicians

- Intervention - what? Emphasis towards the identification of the factors relevant in the establishment and sustainability clinical legal education programmes

- Comparison - compared with what? The influential factors compared with each other. Developed countries' approaches and experiences with clinical legal education and the utilisation of a lecture/seminar discussion format to the teaching of substantive law

- Evaluation - with what results? A better understanding of the impact on legal education in Zimbabwe of social factors, economic factors, political factors, cultural factors, historical factors and other practical issues in the establishment and sustainability of clinical legal education programmes in order to inform policy and reform

My research question was therefore defined in terms of its components according to five common features as set out in the SPICE framework.

\section{Reputable data sources and search tools}

My research on legal education and professional skills considers law in the context of broader social and economic issues; hence it is a socio-legal study. From that perspective, it is interdisciplinary and equally a human and social science study that 
reflects a multidisciplinary research approach on law, on education and on professional skills. It is this interdisciplinary and multidisciplinary approach in my research that justified the selection of legal and non-legal databases suitable to retrieve clinical scholarship that would be relevant in answering my research question. Besides the online legal databases such as Hein Online, LexisNexis, Lawtel and Westlaw, other databases outside of law that provide reputable sources proved difficult to find. The non-legal database, Web of Knowledge (Web of Science) proved valuable as a premier research platform for information in the social sciences, arts and humanities and provided valuable information on clinical legal education.

\section{Performing the search}

The search conducted for this particular review was rigorous, time consuming and extremely episodic. At first, I was tempted to type into the databases, the whole research question as it was. The databases returned no results because they could not make sense of the whole sentence. It was only when I decided to break down my research question into key words and turn them into searchable terms and phrases that I began to retrieve journal articles from the databases.

\section{Identifying key words}

Clinical legal education is referred to by different terms that essentially mean one and the same thing such as law clinic, clinical programme, student law office, clinical legal education programme, legal aid clinic and clinic. To find out more about that one 
programme called clinical legal education there had to be at least a further five terms or phrases that I had to use. This was the most challenging aspect of the first stage of the Systematic Review until I decided to seek help. Apart from the regular support and suggestions by my PhD supervisor, I benefited immensely from the support of the members of the library team at the University of Northumbria's City Campus library who offered guidance on planning the review process. An example of a key phrase I coined for the review following a one to one session with a librarian was clinical legal education.

\section{Conceptualising the research question}

The research question was divided into 3 separate concepts:

- Topic 1 (establishment/development/sustainability of clinical legal education)

- Topic 2 (management of a law clinic)

- $\quad$ Topic 3 (pedagogy of a law clinic)

Synonyms were written down for each topic:

- Topic 1 - establishment of clinical legal education (start, initiation, formation, inception, creation, construction, foundation); development of clinical legal education (growth, expansion, evolution, progress, spread); sustainability of clinical legal education (defendable, defensible, justifiable, maintainable, supportable, continuity, consistency, persistence, perseverance)

- Topic 2 - management of a law clinic (administration, managing, running, organising) 
- Topic 3 - pedagogy of a law clinic (direction, indoctrination, guidance, teaching, education, enlightenment, learning, instruction, scholarship, tuition, training, tutoring, study, apprenticeship, coaching)

This process allowed me to adopt a search strategy that involved the breaking down of the review question into searchable keywords and search terms; the application of an eligibility criteria and the adoption of an inclusion and exclusion process as follows:

\section{Excluded}

- clinical education in the healthcare professions

- development of clinical education in the healthcare professions

- management of clinic in the healthcare professions

- $\quad$ pedagogy for clinic in the healthcare professions

Search Limits

- Language - English language,

- Geography - Global (including UK, USA, Europe, Asia, Australia and Africa)

- Years - All years

- Types - peer-reviewed publications, articles and books

\section{Keywords and String Searches}

- legal education AND clinical legal education AND Zimbabwe

- legal education AND Zimbabwe

- law clinic AND Zimbabwe

- legal aid clinic AND Zimbabwe

- $\quad$ clinical legal education AND University of Zimbabwe

- clinical legal education AND Midlands State University

- clinical legal education AND Midlands State University AND Zimbabwe

- clinical legal education programmes AND management AND opposition

- clinical legal education

- clinical legal education programmes

- challenges AND developing AND clinical legal education programme

- $\quad$ establishment AND sustainability AND clinical legal education programme

- creating AND maintaining AND clinical legal education programme

- influential factors AND management AND clinical legal education programme 
- $\quad$ legal education in Zimbabwe

- law clinics in Zimbabwe

- legal aid clinic at the university of Zimbabwe

- legal aid clinic at midlands state university

- development of clinical legal education

- management of a law clinic

- $\quad$ pedagogy for law clinic

- $\quad$ clinical legal education programmes in Zimbabwe

The correct format for Boolean operators AND, OR, NOT was adopted and the three different topics or concepts were 'AND'ed and synonyms were 'OR'ed using the Boolean logic. The Boolean operators are based on a method of logic developed by George Boole, a $19^{\text {th }}$ century English mathematician. If the Boolean operator AND is entered between two words or phrases, the search will only bring up journal articles that contain both words and phrases. This will narrow the search. For example, I entered into the databases, clinical legal education AND sustainability. This search yielded journal articles that contained both the phrase and the word. Thus, the more terms I connected with the Boolean operator AND, the fewer search results I found that were relevant to what I was looking for. The use of the Boolean operator AND throughout the systematic search was effective because the more words and/or phrases I connected through the Boolean operator AND, the fewer results I retrieved as all terms were present in every match. I found out that using this strategy reduced the number of results and increased the likelihood of the results being relevant to the factors relevant in setting up and running of clinical legal education programmes. 
The use of the Boolean operator AND proved vital in progressing the research on clinical legal education. Its use enabled the research to avoid reinventing the wheel. The Boolean operator's effectiveness lies in the results yielded through a search that combined the phrase legal education with the search terms, Zimbabwe; University of Zimbabwe and Midlands State University; all of which were research fieldwork cases for the collection of research data. It was therefore important that I started off by searching for publications addressing legal education and professional skills in Zimbabwe as a way of corroborating and defending a knowledge claim, which I made at the commencement of my research, that there was a lack of research on clinical legal education in Zimbabwe, particularly on factors relevant in the creation and sustainability of law clinics.

Where the Boolean operator OR is entered between two words or phrases, such a search will look for articles that contain either words or phrases. This will broaden the search. For example, I entered clinical legal education OR clinical programmes. This search yielded articles that contained either phrases but not necessarily both. Thus, the more terms and/or synonyms I connected with the Boolean operator OR, the more search results I found that were relevant to what I wanted. However, there were occasions during the search that the search terms used would produce too few results. One of the temptations I fell into was to use my identified synonyms as they were in the search engines. Doing so gave me too few results and most of them were irrelevant. I then decided to use the Boolean operator OR, in order to increase the 
number of search results. This Boolean operator was used to link similar or synonymous concepts or ideas. The use of this technique helped in retrieving items which contained either or both phrases. Using this technique was quite useful in increasing the number of results retrieved by the search.

Sometimes, we do come across similar words or phrases that might appear to have the same meaning yet mean one thing in one subject area and mean another in a different area of research. For example, it is common for clinical scholarship to refer to clinical legal education as clinical education that is synonymous with studies that are associated with medicine and/or healthcare services. For a novice researcher, this may prove challenging and does create significant difficulties when one is faced with a huge chunk of papers that have something to do with clinical education in medicine and/or healthcare services but nothing to do with clinical education in the operation of a law clinic. In such instances, the Boolean operator NOT comes in handy. Where the Boolean operator NOT is entered between two words or phrases, that search will not bring up articles that contain any words or terms that come after the Boolean operator NOT. This will narrow the search and exclude irrelevant material.

In this review, I came across journal articles on clinical legal education in which authors have used the term clinical education to refer to clinical legal education in the context of the law and not clinical education in context of medicine and/or healthcare services. To avoid bringing up results that had anything to do with learning or 
teaching in medicine and healthcare services, I entered clinical education NOT clinical education in the healthcare profession. This search yielded journal articles containing only information on clinical legal education and nothing on clinical education in the healthcare profession. The more terms I excluded using the Boolean operator NOT, the fewer relevant search results I found that I needed as the Boolean operator NOT restricted journal articles to studies on clinical education in the operation of law clinics and not on clinical education in the healthcare profession. I used the Boolean operator NOT when I had performed a search, looked at the results and decided that I did not want any items that had anything to do with research on medicine and/or healthcare services. Using the Boolean operator NOT reduced the number of results because it excluded items that would have been irrelevant to the aims of the review and only retrieved the ones that would be relevant in answering my research question and achieve the goals of the review.

The review also benefited from the advanced Boolean search techniques that use Quotation Marks ["'] as a way of retrieving relevant journal articles. The use of quotation marks ["“"] narrowed my search for journal articles. Using the phrase clinical legal education on its own, without any quotation marks surrounding the phrase produced so many results. This is because the search treated the words in the phrase as a single word in isolation. I decided to use phrase searching which combined key words surrounded by quotation marks "clinical legal education". The use of this technique reduced the number of items because the quotation marks 
indicate a phrase rather than single words and that made the search more effective. This advanced Boolean search technique required words to be searched as a phrase in the exact order that I had typed them within the quotation marks. I found this technique extremely useful for searching multiple-word terms such as, for example "legal aid clinic", "clinical legal education", "clinical legal education programmes", "Zimbabwe", "University of Zimbabwe", "Midlands State University". I noticed that using quotation marks in my search gave me different search results than those that were yielded by a search using the Boolean operator AND, between each word/phrases without quotes.

As I became more confident in using the Boolean operators to search for literature, I decided to use the operators in a more advanced manner by using the parentheses [()] technique to build my search with a combination of Boolean operators. I enclosed search terms and their operators in parentheses to specify the order in which they are interpreted. Information within parentheses is read first and then information outside parentheses is read next. For example, when I entered into the databases, (challenges OR developing) AND clinical legal education, the search engines returned results containing the word challenges or the word developing together with the search term clinical legal education in the fields searched by default. The use of parentheses technique allowed me to combine any of the Boolean operators together in a combination. Thus, the use of AND together with the Boolean operator OR broadened my search. By using this search string, I found journal articles that had 
everything to do with clinical legal education as it relates to challenges facing such programmes particularly opposition from different stakeholders who are against the introduction of law clinics within law schools.

The addition of a truncation $\left[{ }^{*}\right]$ on key words and/or synonyms gave me a few results. For example, the search term establishment, when truncated [establish*] took me back to a point where the word began to change into many words such as establishing; established. I also discovered that most of the databases I used allow truncation searches using the truncation symbol, i.e. asterisk $\left[{ }^{*}\right]$. I discovered that using truncation increased the number of results as the items had to contain the various forms of the key word.

\section{SYSTEMATIC REVIEW RESULTS}

Electronic searches conducted from the $20^{\text {th }}$ January 2014 until the $7^{\text {th }}$ April 2014 identified 8904 journal articles from selected databases as follows:

Table 1 - Quantity of included articles

\begin{tabular}{|l|l|l|}
\hline Database & Number of Hits & Retained as Potentially Relevant \\
\hline Westlaw & 487 & 103 \\
\hline Hein Online & 5798 & 518 \\
\hline Lawtel & 23 & 7 \\
\hline LexisNexis & 140 & 49 \\
\hline Web of Knowledge & 2456 & 82 \\
\hline Total & 8904 & 759 \\
\hline
\end{tabular}


The journal articles were subjected to a de-duplication process in which duplicates were identified and removed. This stage was followed by a further two-stage process that included, firstly, the screening of titles and abstracts and secondly, the selection of full-text journal articles for inclusion in the review. The de-duplication process left 759 journal articles to be screened for inclusion. These journal articles were subjected to an analysis of their titles and abstracts for relevance in answering the research question. Through an examination of the titles and abstracts and a reading of the introductions and conclusions of this batch of papers, 503 journal articles were excluded. This is because their contents did not relate to my research area and their findings were not relevant to the aims and objectives of my review.

The screening stage resulted in 256 journal articles being obtained and subjected to further scrutiny in the second stage which involved obtaining full-texts of these journal articles. These articles were subjected to further scrutiny in the selection stage to determine the extent to which they addressed factors that are influential in the establishment and sustainability of clinical legal education programmes within law schools. The aim of this review was not to find articles that discuss the entire broader topic of experiential learning and teaching per se. It is accepted that clinical legal education literature can be viewed through the lens of major differences in theory and approach, this review did not specifically set to address those differences that form distinct poles on various continuums such as, among others, very specific 
learning objectives or more general learning objectives; classroom student learning or field placements student learning.

The review aimed at retrieving articles that have identified those crucial factors we ought to take into consideration when we plan to create clinical programmes or sustain clinical those that are already in existence. Out of the potentially relevant batch of 256 papers, 91 papers were selected as relevant. A further batch of 165 articles were excluded because they either addressed the differences in theory and approach of clinical programmes and/or the benefits of clinical legal education without specifically mentioning the crucial factors that we should consider to be relevant in the establishment and sustainability of clinical legal education. The results of the systematic review and identification of the included articles are presented overleaf in the form of a PRISMA flow diagram: 


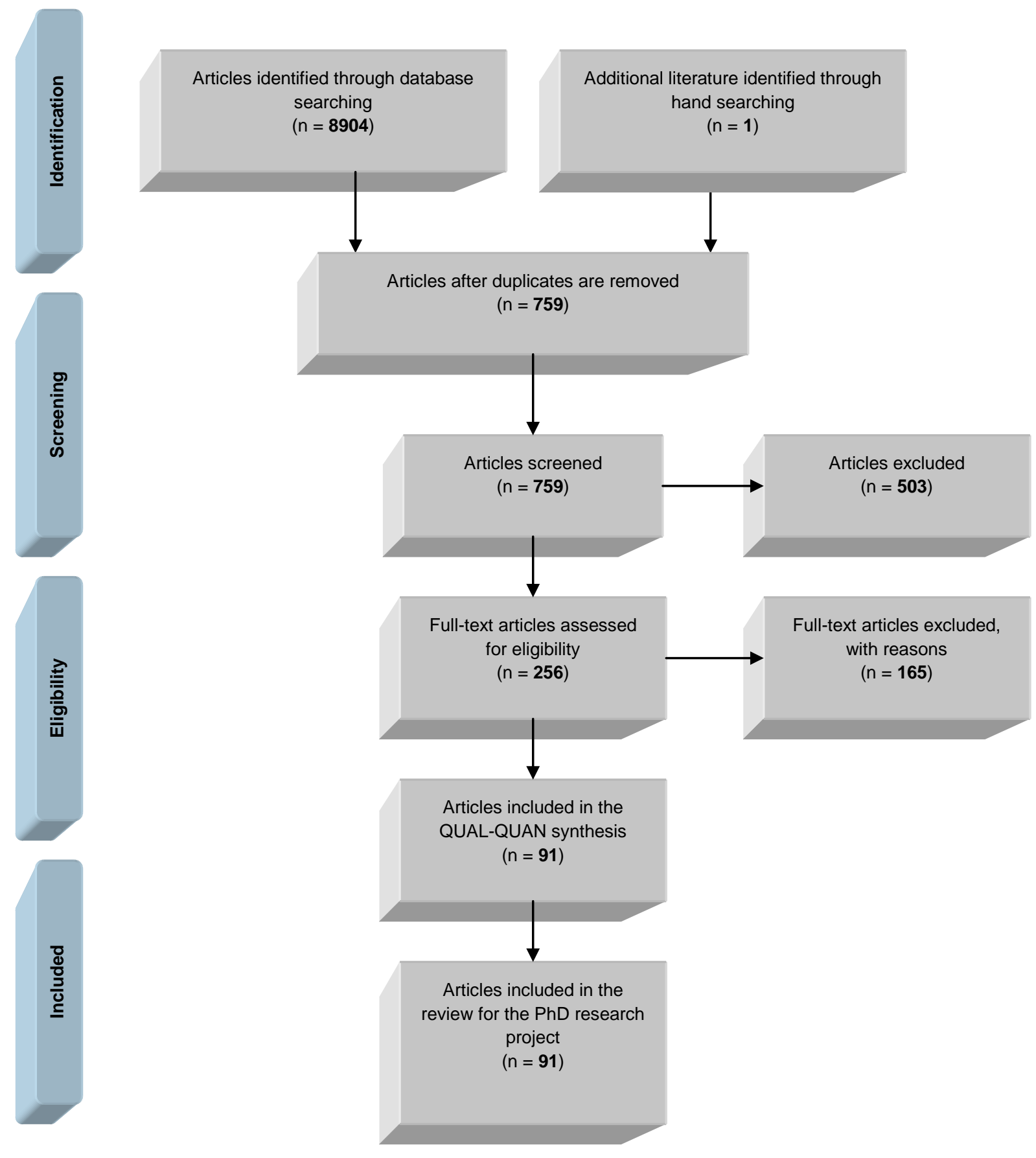

A diagram showing the flow of information through the Systematic Review stages (Courtesy of the PRISMA-Statement.org) 
From the onset of the search strategy and throughout the search process, I established that the electronic databases I chose could only pick up on the title, subject heading and abstract of the article as the authors had written it. I had no doubt that academic peer-reviewed articles are the best source of data for Systematic Reviews. Nevertheless, I consistently remained vigilant throughout the search process for misleading articles. I had to be on the watch out for authors who may not have given sufficient information for the abstract to be picked up as some abstracts may give a misleading picture of the contents of the article. I therefore decided to widen my search outside the narrow confines of the electronic search to include other methods of searching, such as manual examination of printed journals and looked at other forms of information such as, for example, conference proceedings that I have attended both at local and international levels.

There are specific sources in clinical legal education where materials are not published in electronic databases but the material is collated in books which, in response to the needs of clinicians and the research community, is beginning to centralise relevant and up to date information about the global clinical movement. An example of a more centralised clinical resource, I found extremely useful and therefore included in my review, is the book edited by Frank S Bloch, entitled The Global Clinical Movement: Educating Lawyers for Social Justice, published in 2011 by Oxford University Press. I got to know of this source through contact with one of the experts in the field, an Associate Dean with the Faculty of Business and Law at the 
University of Northumbria, United Kingdom. It can sometimes be worthwhile to contact experts in the field who are familiar with the literature and who might be able to advise reviewers of any unpublished studies of which they are aware.

There is no doubt that following up references and hand searching individual journal contents pages can link one up with supplements, news items or indeed clinicians who may have additional information about other research undertaken on clinical legal education. Such additional steps can help to avoid bias in the selection of articles. Sometimes it is easy to take only the more readily accessible material, which is in the major indexed databases. However, such an approach could potentially defeat the aim of rigour that is associated with a Systematic Review process. Much of the evidence on the factors we ought to consider relevant in the establishment and sustainability of clinical programmes may lie in grey literature and to avoid missing out on information on clinical activity, particularly in Zimbabwe, I searched websites of institutions of higher learning in Zimbabwe where there was some written evidence of clinical activity within that jurisdiction. However, that information was skeletal and only referred to the existence of legal aid clinics and not the factors I was investigating hence its ultimate exclusion from my review.

The consideration of unpublished and grey literature was, nevertheless, essential for minimising the potential effects of publication bias. Published studies cannot be 
assumed to be an accurate representation of the whole evidence base, as studies that show significant, positive results are more likely to be published than those that do not (Dickersin 1997). Consequently, if Systematic Reviews are limited to published studies, they risk excluding vital evidence and yielding inaccurate results, which are likely to be biased to positive research outcomes. It was therefore considered essential that active and extensive searching for unpublished and grey literature be undertaken as part of the review process for the identification of influential factors we ought to consider relevant in the establishment and sustainability clinical programmes.

\section{SUMMARY OF THE QUANTITATIVE SYNTHESIS}

The information from the summary tables below illustrates the geographical spread of clinical scholarship reviewed. Research on factors that are influential in the establishment and sustainability of clinical legal education programmes is predominantly carried out in the United States rather than in countries in Europe, including the United Kingdom. There are a significant number of research papers from Australia as compared to other jurisdictions but relatively less so in some parts of the world particularly in Africa. 
Table 2 - Geographical spread of articles by country

\begin{tabular}{|l|l|}
\hline Countries clinic studied & Number of articles per country \\
\hline United States of America & 35 \\
\hline England, United Kingdom & 11 \\
\hline Australia & 10 \\
\hline China & 4 \\
\hline Canada & 3 \\
\hline Ireland & 3 \\
\hline Nigeria & 3 \\
\hline South Africa & 3 \\
\hline Croatia & 2 \\
\hline Poland & 2 \\
\hline Botswana & 1 \\
\hline Chile & 1 \\
\hline Czech Republic & 1 \\
\hline Fiji & 1 \\
\hline Germany & 1 \\
\hline Iraq & 1 \\
\hline Japan & 1 \\
\hline Jordan & 1 \\
\hline Kenya & 1 \\
\hline New Zealand & 1 \\
\hline Palestine & 1 \\
\hline Romania & 1 \\
\hline Scotland, United kingdom & 1 \\
\hline Taiwan & 1 \\
\hline Togo & 1 \\
\hline Total number of countries (n=25) & Total number of articles $(\mathrm{n}=91)$ \\
\hline & \\
\hline
\end{tabular}

As can be seen from the table above, there is therefore a real, strong geographical bias within the global clinical movement itself with the United States topping the table of the location where research on influential factors to consider in the creation and sustainability of clinical programmes is carried out. Literature on clinical legal education in Africa reveals quite a bit of clinical activity in South Africa and Nigeria but less so in other parts of the continent. It would be very interesting to find out why there is little or no clinical activity at all elsewhere in Africa and those research findings should be documented. Any arising issues should be addressed and acted upon by the global clinical movement, if we are to say with certainty, that clinical 
legal education has a global reach. Hopefully, this trend will change in the near future as there now seem to be a lot of clinics emerging from elsewhere around the globe.

Table 3 - Geographical spread of articles by region

\begin{tabular}{|l|l|l|}
\hline Region & Country in which the clinic is located & Number of articles per country \\
\hline \multirow{5}{*}{ Africa $(\mathrm{n}=9)$} & Nigeria & 3 \\
\cline { 2 - 3 } & South Africa & 3 \\
\cline { 2 - 3 } & Botswana & 1 \\
\cline { 2 - 3 } & Kenya & 1 \\
\cline { 2 - 3 } & Togo & 1 \\
\hline \multirow{5}{*}{ Americas (n=39) } & United States of America & 35 \\
\cline { 2 - 3 } & Canada & 3 \\
\cline { 2 - 3 } & Chile & 1 \\
\hline Europe (n=22) & Australia & 10 \\
\cline { 2 - 3 } & Fiji & 1 \\
\cline { 2 - 3 } & Japan & 1 \\
\cline { 2 - 3 } & New Zealand & 1 \\
\hline \multirow{5}{*}{ Total number of regions $(\mathrm{n}=5)$} & England, United Kingdom & 11 \\
\cline { 2 - 3 } & Ireland & 3 \\
\cline { 2 - 3 } & Croatia & 2 \\
\cline { 2 - 3 } & Poland & 2 \\
\cline { 2 - 3 } & Czech Republic & 1 \\
\cline { 2 - 3 } & Germany & 1 \\
\cline { 2 - 3 } & Romania & 1 \\
\cline { 2 - 3 } & Scotland, United kingdom & 1 \\
\hline \multirow{5}{*}{ Middle East and Asia $(\mathrm{n}=8)$} & China & 4 \\
\cline { 2 - 3 } & Iraq & 1 \\
\cline { 2 - 3 } & Jordan & 1 \\
\cline { 2 - 3 } & Palestine & 1 \\
\cline { 2 - 3 } & Taiwan & Total number of articles $(\mathrm{n}=91)$ \\
\hline
\end{tabular}

The results from the table above indicate a very strong regional bias in the publication of studies that address factors we should consider crucial and hence relevant in our efforts to establish and sustain clinical programmes. However, as can be seen from the table, most journal articles come from those countries that have developed economies and stable democracies and less so from regions where the operations of the clinic could be affected by socio-economic and political turmoil. 
The question therefore is: can we conclude, with certainty, that clinical legal education has a global reach when there is little or no evidence of whether or not the relevant factors identified from clinical scholarship on clinic in developed countries can equally apply to the clinic in those regions where there is little or no evidence of research? It is arguable therefore that until we have studies reporting on the creation and sustainability of clinical programmes from all regions where there is clinical activity there can be no consensus with the assertion that clinical legal education has a global reach.

Table 4 - Geographical spread of articles by time of publication

\begin{tabular}{|l|l|l|l|l|l|}
\hline $\begin{array}{l}\text { Decade articles } \\
\text { produced }\end{array}$ & Africa & Americas & $\begin{array}{l}\text { Australasia and } \\
\text { Pacific }\end{array}$ & Europe & $\begin{array}{l}\text { Middle East } \\
\text { and Asia }\end{array}$ \\
\hline $1950-70$ & & 1 & & & \\
\hline $1971-90$ & & 4 & & & \\
\hline $1991-2000$ & & 10 & 3 & 3 & 14 \\
\hline $2001-2010$ & 6 & 15 & 8 & 5 & 3 \\
\hline $2011-2014$ & 3 & 9 & 2 & & 5 \\
\hline
\end{tabular}

As can be seen from the table above, the period from the 1950s up to about the beginning of the millennium, clinical scholarship has been about clinic outside of Asia and Africa but more so from the United States followed by Australia and Europe within the decade leading to the millennium. However, this trend seems to be changing with more clinics created globally. There is an interesting trend in the surge of evidence of clinical activity between 2001 and 2010 from all regions including Asia and Africa. As we all know, this was a period of an economic recession and it could be that as people were losing jobs, law firms closing offices 
and governments streamlining their spending budgets, the demand for free legal advice became higher than ever before and inevitably led to a surge in the creation of clinical programmes as an alternative avenue for legal services delivery. Even though we still have a lot of clinical scholarship addressing factors relevant in the creation and sustainability of clinical programmes from the Americas, Europe and Australasia and the Pacific, we now have quite a few articles drawing from the operations of the clinic in Asia and Africa from 2001 till to date. While the potential impact, on the global clinical movement, of research on the creation and sustainability of clinical programmes in Asia and Africa is yet to be felt, there seems to be some keenness amongst clinicians from these regions to share their experiences in creating and sustaining clinical programmes from their local bases. However, despite this keenness, it is still difficult to predict exactly when research on clinic in Asia and Africa will be at par with research from the rest of the world.

The table overleaf is illustrative of where most clinical legal education authors are based. Out of a batch of ninety-one clinical scholarship papers, forty-four articles are by authors from the United States. This number could be more if we knew where the anonymous author writing about clinic in China is based. A closer look at the table above indicates an interesting trend. Journal articles selected for the review are predominantly written by authors based in the United States for the clinic in the United States. Not only do the United States based authors write for the clinic in the 
United States, they also write for the clinic in the Americas region except for Canada.

Table 5 - Geographical spread of articles by where authors are located

\begin{tabular}{|c|c|c|}
\hline Region for clinic & Country in which the authors are located & $\begin{array}{l}\text { Number of articles } \\
\text { per country }\end{array}$ \\
\hline Africa $(n=9)$ & $\begin{array}{l}\text { Nigeria (Authors of the three articles and their co-authors are all based } \\
\text { locally) } \\
\text { South Africa (Authors of the two articles are locally based) } \\
\text { United States ( One author is based in the U.S but was in South Africa for a } \\
\text { while; The author of the other article is based in the U.S was briefly in Togo } \\
\text { as Consultant) } \\
\text { Botswana (Author is locally based) } \\
\text { Kenya (Author is locally based) }\end{array}$ & $\begin{array}{l}\mathrm{n}=3 \\
\mathrm{n}=2 \\
\mathrm{n}=2 \\
\mathrm{n}=1 \\
\mathrm{n}=1\end{array}$ \\
\hline Americas $(\mathrm{n}=39)$ & $\begin{array}{l}\text { United States (Twenty two different authors based in the U.S have } \\
\text { published as single authors; Six have published either on their own or with } \\
\text { others locally based or with others that are based abroad. One author is } \\
\text { based in U.S but writes about clinic in Chile) } \\
\text { Canada (Main authors in three articles are locally based) }\end{array}$ & $\mathrm{n}=36$ \\
\hline $\begin{array}{l}\text { Australasia and the } \\
\text { Pacific }(n=13)\end{array}$ & $\begin{array}{l}\text { Australia (Main author and a co-author are both based locally; Main author } \\
\text { and three other co-authors are based locally) } \\
\text { England (Author is originally from England but have been in Fiji for a } \\
\text { while as a Consultant) } \\
\text { New Zealand (Author is originally from England but now settled in } \\
\text { Auckland) } \\
\text { United States (Main author and another co-author are locally based but the } \\
\text { other two co-authors are from Japan) }\end{array}$ & $\begin{array}{l}\mathrm{n}=10 \\
\mathrm{n}=1 \\
\mathrm{n}=1 \\
\mathrm{n}=1\end{array}$ \\
\hline Europe $(n=22)$ & $\begin{array}{l}\text { England (Main authors and co-authors in eleven articles are locally based; } \\
\text { Ireland (Three main authors and one co-author in three are locally based) } \\
\text { Croatia (Two authors in two articles are locally based) } \\
\text { Poland (Two authors in two articles are locally based) } \\
\text { Czech Republic (Main author and two co-authors are locally based) } \\
\text { Germany (Author is locally based) } \\
\text { Romania (Author is locally based) } \\
\text { Scotland (Author is locally based) }\end{array}$ & $\begin{array}{l}\mathrm{n}=11 \\
\mathrm{n}=3 \\
\mathrm{n}=2 \\
\mathrm{n}=2 \\
\mathrm{n}=1 \\
\mathrm{n}=1 \\
\mathrm{n}=1 \\
\mathrm{n}=1\end{array}$ \\
\hline $\begin{array}{l}\text { Middle East and } \\
\text { Asia }(\mathrm{n}=8)\end{array}$ & $\begin{array}{l}\text { United States (Author is based in the U.S. but writes about clinic in China; } \\
\text { Main author is based in the U.S based and co-author is based in China) } \\
\text { Anonymous (It is unknown where Anonymous is based but writes about } \\
\text { clinic in China) } \\
\text { China (Author is locally based) } \\
\text { Palestine (Author is locally based) } \\
\text { United States (Author is originally from Iraq but is now based in U.S. Briefly } \\
\text { went back to Iraq to create clinic) } \\
\text { United States (Main author is based in the U.S but went to Jordan as a } \\
\text { Consultant and the co-author is locally based) } \\
\text { United States (Author is based in the U.S but worked in Taiwan and created } \\
\text { a clinic there) }\end{array}$ & $\begin{array}{l}\mathrm{n}=2 \\
\mathrm{n}=1 \\
\mathrm{n}=1 \\
\mathrm{n}=1 \\
\mathrm{n}=1 \\
\mathrm{n}=1\end{array}$ \\
\hline
\end{tabular}

What is interesting though is that we do not have evidence of authors outside of the

United States writing about the clinic in the United States yet we have quite a

number of United States based authors consulting in all other regions but not in 
Europe. Europe based authors mostly write about the clinic in their own localities except for one article written by an English author who was briefly tasked with creating a clinic in Fiji. There is therefore a lot of consulting by the United States based authors as compared to Europe based authors. While there is nothing wrong with having the United States authors topping the table in relation to writing on the creation and sustainability of clinical legal education programmes both within and outside the United States there is a danger that this border transcending dominance may influence how we view research by colleagues in the United States. In the process, we may even attach a higher status to such work at the expense of similar research carried out elsewhere. Subsequently, we may end up believing that our research questions can only be answered by referring to such work and nothing else. Such an approach leads to citation bias. While we have to applaud colleagues from North America for undertaking research on the clinical movement and in the process riding high on the research treadmill, we need to encourage each other to publish more on the clinic where we are based and value such research.

There seems to be a growing interest in clinical legal education topics, particularly around the factors we should consider relevant in the establishment and sustainability of clinical programmes within law schools. A closer look at the table below is testimony to this assertion 
Table 6 - Geographical spread of articles by publication in academic journals

\begin{tabular}{|c|c|c|c|c|c|c|}
\hline Academic Journal & Africa & Americas & $\begin{array}{l}\text { Australasi } \\
\text { a and the } \\
\text { Pacific }\end{array}$ & Europe & $\begin{array}{l}\text { Middle } \\
\text { East and } \\
\text { Asia }\end{array}$ & $\begin{array}{l}\text { Articles } \\
\text { per } \\
\text { Journal } \\
\end{array}$ \\
\hline IJCLE & 4 & 5 & 4 & 12 & & $\mathrm{n}=25$ \\
\hline Clinical Law Review & & 10 & 1 & & 1 & $\mathrm{n}=12$ \\
\hline Griffith Law Review & 2 & & 1 & 1 & & $\mathrm{n}=4$ \\
\hline Fordham International Law Journal & 1 & 2 & & & & $\mathrm{n}=3$ \\
\hline German Law Journal & & 1 & & 2 & & $\mathrm{n}=3$ \\
\hline $\begin{array}{l}\text { Berkeley Journal of Middle Eastern and } \\
\text { Islamic Law }\end{array}$ & & & & & 2 & $\mathrm{n}=2$ \\
\hline Legal Education Review & & & 1 & & 1 & $\mathrm{n}=2$ \\
\hline Newcastle Law Review & & & 2 & & & $\mathrm{n}=2$ \\
\hline New York Law School Law Review & & 2 & & & & $\mathrm{n}=2$ \\
\hline Osgoode Hall Law Journal & & 2 & & & & $\mathrm{n}=2$ \\
\hline Phoenix Law Review & & 1 & & 1 & & $\mathrm{n}=2$ \\
\hline University of Michigan Journal of Law Reform & & 2 & & & & $\mathrm{n}=2$ \\
\hline Alternative Law Journal & & & 1 & & & $\mathrm{n}=1$ \\
\hline Boston College of Law Journal & & 1 & & & & $\mathrm{n}=1$ \\
\hline Case Western Reserve Law Review & & 1 & & & & $\mathrm{n}=1$ \\
\hline Cleveland State Law Review & & 1 & & & & $\mathrm{n}=1$ \\
\hline Columbia Journal of East European Law & & & & 1 & & $\mathrm{n}=1$ \\
\hline Commonwealth Law Bulletin & & & 1 & & & $\mathrm{n}=1$ \\
\hline $\begin{array}{l}\text { Comparative and International Law Journal of } \\
\text { Southern Africa }\end{array}$ & 1 & & & & & $\mathrm{n}=1$ \\
\hline $\begin{array}{l}\text { Criminal Law and Justice Weekly Journals } \\
\text { Index }\end{array}$ & & & & 1 & & $\mathrm{n}=1$ \\
\hline Denver Law Journal & & 1 & & & & $\mathrm{n}=1$ \\
\hline Drexel Law Review & & 1 & & & & $\mathrm{n}=1$ \\
\hline Georgetown Journal of Legal ethics & & 1 & & & & $\mathrm{n}=1$ \\
\hline Harvard Law Review & & & & & 1 & $\mathrm{n}=1$ \\
\hline Journal of College and University Law & & 1 & & & & $\mathrm{n}=1$ \\
\hline Journal of Law and Society & & & & 1 & & $\mathrm{n}=1$ \\
\hline Journal of Legal Education & & 1 & & & & $\mathrm{n}=1$ \\
\hline McGeorge Law Review & & & & & 1 & $\mathrm{n}=1$ \\
\hline Michigan Journal of International Law & & 1 & & & & $\mathrm{n}=1$ \\
\hline National Taiwan University Law Review & & & & & 1 & $\mathrm{n}=1$ \\
\hline Nebraska Law Review & & 1 & & & & $\mathrm{n}=1$ \\
\hline $\begin{array}{l}\text { Pacific McGeorge Global Business and } \\
\text { Development Law Journal }\end{array}$ & & & & & 1 & $\mathrm{n}=1$ \\
\hline Potchfstroom Electronic Law Journal & 1 & & & & & $\mathrm{n}=1$ \\
\hline SCOLAG & & & & 1 & & $\mathrm{n}=1$ \\
\hline Southern California Law Review & & 1 & & & & $\mathrm{n}=1$ \\
\hline Tennessee Law Review & & 1 & & & & $\mathrm{n}=1$ \\
\hline The Law Teacher & & & & 1 & & $\mathrm{n}=1$ \\
\hline The New Law Journal & & & & 1 & & $\mathrm{n}=1$ \\
\hline University of New South Wales Law Journal & & & 1 & & & $\mathrm{n}=1$ \\
\hline University of Pennsylvania Law Review & & 1 & & & & $\mathrm{n}=1$ \\
\hline $\begin{array}{l}\text { Washington University Journal of Law and } \\
\text { Policy }\end{array}$ & & & 1 & & & $\mathrm{n}=1$ \\
\hline Windsor Yearbook of Access to Justice & & 1 & & & & $\mathrm{n}=1$ \\
\hline Total & & & & & & $\mathrm{n}=91$ \\
\hline
\end{tabular}


There seems to be a growing interest in clinical legal education topics, particularly around the factors we should consider relevant in the establishment and sustainability of clinical programmes within law schools. A closer look at the table above is testimony to this assertion. As can be seen, a good example is the acceptance of clinical articles from across the globe by the International Journal of Clinical Legal Education (IJCLE). This is an exciting development, particularly for some of us who have just got onto the research treadmill and are so keen to remain on it for as long as we continue to have the capacity to think intellectually and the ability to type away. As clinical researchers, our reputation and career prospects are largely determined by our publications in academic journals. Taking the Clinical Law Review academic journal as an example, the New York University website states the following about the review:

The Clinical Law Review is a semi-annual peer-edited journal devoted to issues of lawyering theory and clinical legal education. The Review is jointly sponsored by the Association of American Law Schools (AALS), the Clinical Legal Education Association (CLEA), and New York University School of Law.

None of the articles reviewed were from members affiliated with the institution. Again there seem to be no bias in the Clinical Law Review's selection of articles for publication. A further examination of the information from the table above has also 
revealed an interesting trend. While there is a presumption that law reviews publish more articles from colleagues at their own mother institutions than from academics and practitioners based in other law schools, the twelve articles published in the Clinical Law Review (three by one author and nine by others) have shown that all the ten authors whose work has been published by the review are from outside New York University but all are based in the United States. These highly cited authors include, among others, Peter A. Joy (1998, 2004, 2006); Peggy Maisel (2008); Richard J. Wilson (2002); Irene Scharf (2006); and Phillip Schrag (1997).

It is not surprising though that a law review with the word 'clinic' would attract the attention of such notable clinicians. Sometimes it is much easier to associate a journal with the type of articles it publishes by merely looking at the wording of the names it is called by. Griffith Law Review is another good example of a law review that publishes clinical articles, as are the Newcastle Law Review and the Phoenix Law Review. As such we can confidently conclude that clinical journals produce more clinic papers than anywhere else. However, this trend does not necessarily mean that other academic journals do not accept clinic papers. For example, the Berkeley Journal of Middle Eastern \& Islamic Law is a digital, student-run publication of the University of California's Law School in Berkeley and is not exclusively a clinical legal education journal. Yet it does accept papers on this area of law, particularly from the Middle East and Asia. Fordham University's website states the following: 
Currently in its $35^{\text {th }}$ year of publication, the Fordham International Law Journal is one of the most competitive international law periodicals in the world and, according to a recent study, one of the most frequently cited student-edited legal publications dedicated to the study of international law.

The fact that we have these examples of academic journals also publishing material on clinical legal education is indicative of an acceptance of clinical legal education as a discipline and topics on clinical programmes as publication material worthy of a slot in academic journals regardless of ownership and location of the publisher. It is a widely held view that academic journals are representative of quality in publication of journal articles. While it is accepted that every article worthy of publication must be of high quality we know too well that proxy for quality has created two lenses upon which academic journals are viewed, i.e. prestigious journals and less-prestigious journals. There is a presumption that prestigious academic journals publish journal articles of higher quality than the less-prestigious academic journals. Likewise, where journals have evidence of just one article published on clinical legal education as shown in the table, the trend could mean that different academic journals have different levels of prestige. Their status is measured by their impact factor, a citation-based measure of the perceived importance of a journal in its field. However, the fact that there is evidence of acceptance of clinical scholarship from a wide spectrum of journals as evidenced by 
the information from the table above, means that as clinician researchers, we have to respond to this wide acceptance by publishing more widely too.

This Systematic Review did not aim solely to identify and merely bring together relevant clinical legal education papers that specifically identified and discussed those factors relevant in the establishment and sustainability of clinical programmes. Selected journal articles from the five databases were juxtaposed through a process of synthesis to identify patterns and direction in findings. The selected articles were integrated and tabulated to produce an overarching explanation which attempts to account for the range of findings (Mays et al., 2005a). Through the process of synthesis I endeavoured to contribute significant added value to my review through an examination of the composite evidence base for similarities in my chosen selection of papers, whether related to the homogeneity of the papers (i.e. how they were carried out, where, when, why and by who) or indeed their relatedness of findings (i.e. what they found in their identification of those crucial factors we consider influential in the creation and sustainability of clinical programmes) as illustrated by the table below:

The example below of a categorised article is representative of all of the 91 articles selected for the review. The types of articles selected are qualitative in nature. They use a Case Study methodology and adopt an observational approach with a descriptive twist to their aims and their findings. 
Table 7 - Example of a categorised journal article

\begin{tabular}{|c|c|c|c|c|c|c|c|c|}
\hline Author & Date & Title & Citation & Location & Method & Aim & Findings & Critique \\
\hline Anonymous & 2007 & $\begin{array}{l}\text { Adoptin } \\
\text { g and } \\
\text { Adaptin } \\
\text { g: } \\
\text { Clinical } \\
\text { Legal } \\
\text { Educatio } \\
\mathrm{n} \text { and } \\
\text { Access } \\
\text { to Justice } \\
\text { in China }\end{array}$ & $\begin{array}{l}\text { Harvard } \\
\text { Law } \\
\text { Review, } \\
\text { Vol. 120, } \\
\text { Issue 8, } \\
\text { pp.2134- } \\
2155 .\end{array}$ & $\begin{array}{l}\text { China, } \\
\text { Asia }\end{array}$ & $\begin{array}{l}\text { Qualitative; } \\
\text { Case Study } \\
\text { methodology; } \\
\text { Observational } \\
\text { approach }\end{array}$ & $\begin{array}{l}\text { Examines } \\
\text { China's } \\
\text { importation } \\
\text { and } \\
\text { localisation } \\
\text { of this one } \\
\text { legal } \\
\text { institution, } \\
\text { the United } \\
\text { States of } \\
\text { America } \\
\text { style legal } \\
\text { clinic, with } \\
\text { respect to } \\
\text { one stated } \\
\text { goal of the } \\
\text { importation, } \\
\text { promoting } \\
\text { equal access } \\
\text { to justice in } \\
\text { China }\end{array}$ & $\begin{array}{l}\text { Cross- } \\
\text { jurisdictiona } \\
1 \text { borrowing } \\
\text { of } \\
\text { institutional } \\
\text { models; } \\
\text { legal } \\
\text { transplantati } \\
\text { on; } \\
\text { indigenous } \\
\text { circumstanc } \\
\text { es; spectre of } \\
\text { legal } \\
\text { imperialism; } \\
\text { and the } \\
\text { Chinese } \\
\text { legal } \\
\text { systems are } \\
\text { factors that } \\
\text { are critical } \\
\text { for } \\
\text { consideratio } \\
n \text { in the } \\
\text { establishme } \\
\text { nt and } \\
\text { sustainabilit } \\
\text { y of a } \\
\text { clinical } \\
\text { programme }\end{array}$ & Descriptive \\
\hline
\end{tabular}

In the process, they contributed to an added value of the Case Study methodology as a research strategy to be adopted for the completion of my research on clinical legal education, particularly, the identification of the factors that are influential in the establishment and sustainability of clinical programmes. 


\section{QUALITATIVE QUESTIONS TO BE ADDRESSED IN PAPER 2 OF THE}

\section{SYSTEMATIC REVIEW}

Having gone through how being systematic and quantitative a Systematic Review process can be; having created and developed a personal review database; having put all the information about my selected clinical scholarship into the database and having used that information to create some tables, this paper has discussed, among other things, the various stages in which the method of searching and selecting relevant articles was conducted. The process involved dealing with actual numbers. Relevant journal articles were counted and summary tables were constructed. As can be seen, the whole process involved a transition from the systematic to the quantitative and from the quantitative to the qualitative making it possible for me to notice patterns and to strategically position myself to map out the gaps in knowledge; identify exactly where those gaps are and suggest ways in which we can address those gaps now or indeed in the future. So based on the method discussed in this paper and the assessment of the selected journal articles relevant in answering the research question on the factors we ought to consider relevant in the establishment and sustainability of clinical legal education programmes, the next paper, Mkwebu (2016, in preparation) will describe how a Systematic Review process was combined with a Grounded Theory method to form a nexus that identified the following: 
- What is known (i.e. existing knowledge)

- What is unknown (i.e. the knowledge gaps)

- How I to contribute to knowledge (i.e. suggestions for filling in the knowledge gaps)

\section{CONCLUSION}

To aid my understanding of various worldviews on clinical legal education in general and on the influential factors in the establishment and sustainability of clinical legal education in particular, a Systematic Review of literature became a key method for "locating, appraising, synthesising and reporting best evidence" (Briner et al., 2009: 24). Besides, there is a general agreement that the right method is the one that will answer the research question (Holloway and Todres, 2003) even though it may not always be so obvious. Conducting a Systematic Review of literature was a mammoth task that required a focused effort to complete. Even though I endured months of laborious and tedious construction of the review, it later became apparent that Systematic Reviews are a wise investment of time when researching on clinical legal education as opposed to the more traditional Narrative Reviews that have the freedom to unsystematically pick and choose papers that support one's view; itself a clearly biased approach. 


\section{REFERENCES}

BOLAND, A., CHERRY, G. AND DICKSON, R. 2014. Doing a Systematic Review: A Student's Guide, London: SAGE Publications.

BOOTH, A. 2006. Clear and Present Questions: Formulating Questions for Evidence Based-Practice. Library Hi Tech, 24, 355-368.

BRINER, R., B., DENYER, D. AND ROUSSEAU, D, M. 2009. Evidence-Based Management: Concept Cleanup Time? The Academy of Management Perspective, 23, 19-32.

DENYER, D. AND TRANFIELD, D. 2009. Producing a Systematic Review, London: SAGE Publications.

DICKERSIN K. (1997). How important is publication bias? A synthesis of available data. AIDS Educ Prev, 9(Suppl A),15-21.

FRANK, J. 1933. Why Not a Clinical-Lawyer School? University of Pennsylvania Law Review and American Law Register, 81, 907-923.

HOLLOWAY, I. AND TODRES, L. 2003. The Status of Method: Flexibility, Consistency and Coherence. Qualitative Research, 3, 345-357.

KIRKEVOLD, M. (1997). Intergrative Nursing Research - An Important Strategy to Further the Development of Nursing Science and Practice. Journal of Advanced Nursing, 25, 977-984.

MAYS, N., POPE, C., AND POPAY, J. 2005a. Systematically Reviewing Qualitative and Quantitative Evidence to Inform Management and Policy Making in the Health Field. Journal of Health Services Research and Policy, 10, 6-20.

WEBSTER, J. AND WATSON., R. T. 2002. Analysing the Past to Prepare for the Future: Writing a Literature Review. Management Information Systems Quarterly, 22, 13-23. 